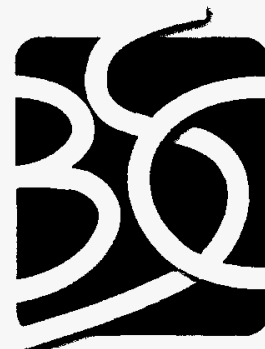

BECHTEL

SAIC CONPANULC

QA: N/A

170-PLN-HA00-00100-000-000

February 2005

\title{
Aging System Design Development Strategy
}

Prepared for:

U.S. Department of Energy

Office of Civilian Radioactive Waste Management

Office of Repository Development

1551 Hillshire Drive

Las Vegas, Nevada 89134-6321

Prepared by:

Bechtel SAIC Company, LLC

1180 Town Center Drive

Las Vegas, Nevada 89144

Under Contract Number

DE-AC28-01RW12101 


\section{DISCLAIMER}

This report was prepared as an account of work sponsored by an agency of the United States Government. Neither the United States Government nor any agency thereof, nor any of their employees, nor any of their contractors, subcontractors or their employees, makes any warranty, express or implied, or assumes any legal liability or responsibility for the accuracy, completeness, or any third party's use or the results of such use of any information, apparatus, product, or process disclosed, or represents that its use would not infringe privately owned rights. Reference herein to any specific commercial product, process, or service by trade name, trademark, manufacturer, or otherwise, does not necessarily constitute or imply its endorsement, recommendation, or favoring by the United States Government or any agency thereof or its contractors or subcontractors. The views and opinions of authors expressed herein do not necessarily state or reflect those of the United States Government or any agency thereof. 


\section{Aging System Design Development Strategy}

\section{Joln Beeseg}

John Beesley

Originator

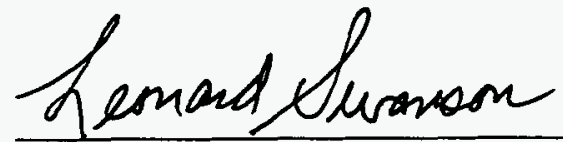

Leonard Swanson

Technical Reviewer

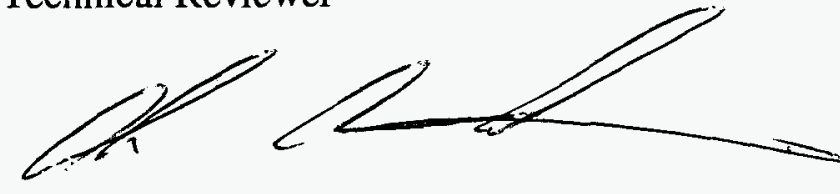

Colin Cochrane

Project Engineer
$2-7-05$

Date

$$
2-7-05
$$

Date

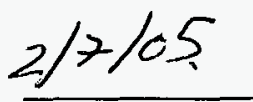

Date 
Aging System Design Development Strategy

INTENTIONALLY LEFT BLANK 


\section{Contents}

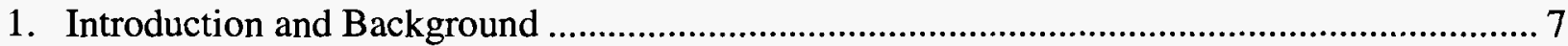

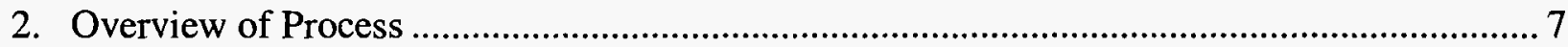

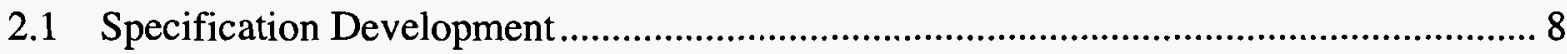

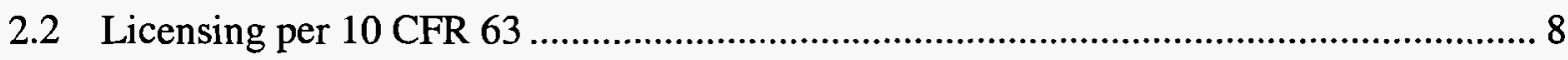

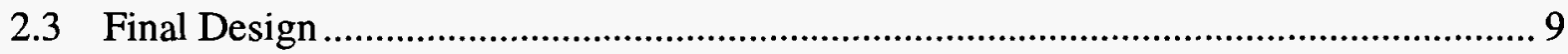

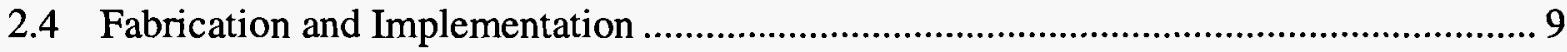

3. Summary of Completed Activities.................................................................................... 9

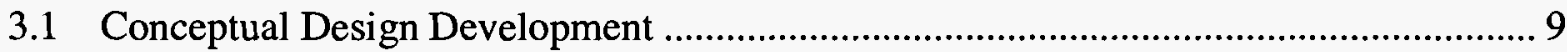

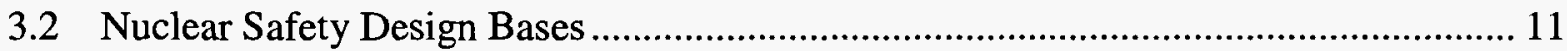

3.3 Recent Aging Strategy, Performance Specification...................................................... 15

3.4 Recent Aging Strategy, Comparative Report........................................................... 16

4. Remaining Activities Leading to Implementation .............................................................. 16

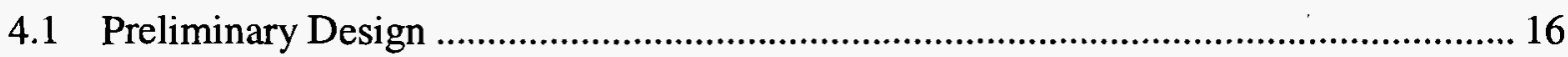

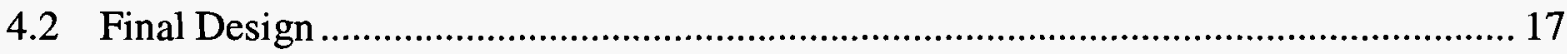

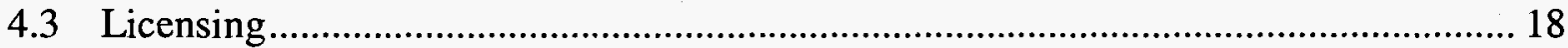

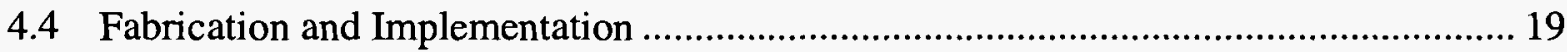

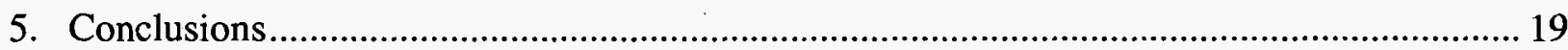

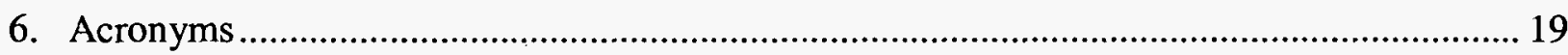

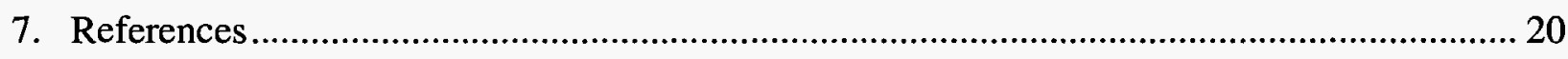

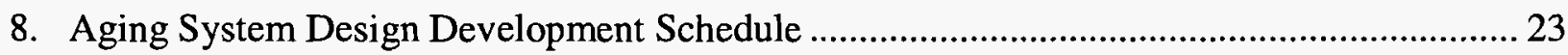




\section{Tables}

Table 1-1 Aging System Waste Types.............................................................................. 7

Table 3-1 Summary of Controlled Aging System Calculations ............................................... 10

Table 3-2 Summary of Controlled Aging System Drawings...................................................... 10

Table 3-3 Cask Tractor, HAM System - Nuclear Safety Design Bases ...................................... 11

Table 3-4 Transfer Trailer, HAM System - Nuclear Safety Design Bases................................... 12

Table 3-5 Site-Specific Cask Transporter - Nuclear Safety Design Bases .................................. 12

Table 3-6 Site-Specific Transfer Cask - Nuclear Safety Design Bases ...................................... 13

Table 3-7 Aging Pad - Nuclear Safety Design Bases ................................................................ 13

Table 3-8 Site-Specific Cask - Nuclear Safety Design Bases..................................................... 14

Table 3-9 Horizontal Aging Module - Nuclear Safety Design Bases......................................... 15

Table 4-1 Preliminary Design Activities ............................................................................. 17

Table 4-2 Final Design Activities ................................................................................... 18

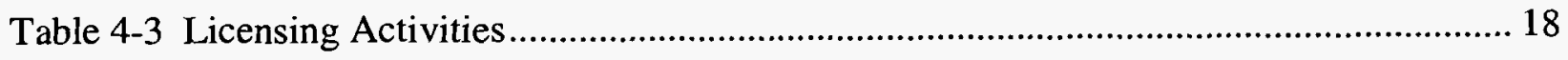

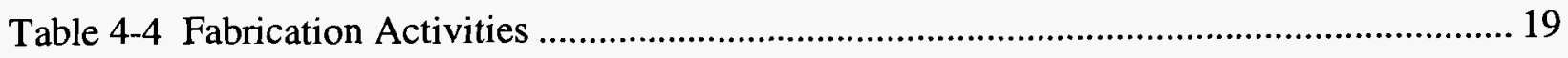

Table 4-5 Implementation Activities ............................................................................... 19 


\section{Introduction and Background}

This plan provides an overview, work to date, and the path forward for the design development strategy of the Aging cask for aging commercial spent nuclear fuel (CSNF) at the Yucca Mountain Project (YMP) repository site. Waste for subsurface emplacement at the repository includes U.S. Department of Energy (DOE) high-level radioactive waste (HLW), DOE SNF, commercial fuel in dual-purpose canisters (DPCs), uncanistered bare fuel, naval fuel, and other waste types. The following table lists the types of radioactive materials that may be aged at YMP, and those materials that will not be placed in an aging cask or module.

Table 1-1 Aging System Waste Types

\begin{tabular}{|l|c|c|}
\hline Radioactive Waste Type & $\begin{array}{c}\text { Candidate for Aging in a } \\
\text { Site-Specific Cask or } \\
\text { Module }\end{array}$ & $\begin{array}{c}\text { Loaded Directly into Waste Packages } \\
\text { and Emplaced Underground }\end{array}$ \\
\hline Horizontal DPCs with CSNF & Yes & No $^{1}$ \\
\hline Vertical DPCs with CSNF & Yes & No $^{1}$ \\
\hline Uncanistered (bare) CSNF & Yes & Yes (if heat output is within established \\
\hline Naval SNF & No & Yes \\
\hline Multi-Canister Overpacks (MCO) & No & Yes \\
\hline DOE High-Level Waste & No & Yes \\
\hline DOE Spent Nuclear Fuel & No & Yes \\
\hline
\end{tabular}

${ }^{1}$ DPCs are not currently certified for emplacement underground. They must be cut open and the SNF assemblies transferred to a waste package prior to subsurface emplacement.

This plan presents the strategy for design development of the Aging system. The Aging system will not handle naval fuel, DOE HLW, MCOs, or DOE SNF since those materials will be delivered to the repository in a state and sequence that allows them to be placed into waste packages for emplacement. Some CSNF from nuclear reactors, especially CSNF that is thermally too hot for emplacement underground, will need to be aged at the repository.

\section{Overview of Process}

The Aging system design development strategy will include design, fabrication, and placement into service of vertical aging casks and horizontal aging modules (HAM)s. The vertical casks, HAMs, and their transportation equipment will be similar to existing systems that are currently licensed under 10 CFR 72, Licensing Requirements for the Independent Storage of Spent Nuclear Fuel, High-Level Radioactive Waste, and Reactor-Related Greater than Class C Waste (10 CFR 72 [DIRS 127267]) and in service at nuclear power plants around the nation. As with the existing storage systems, the Aging cask at YMP will be designed and fabricated by companies that have experience with dry storage of CSNF. 


\subsection{Specification Development}

The current strategy for Aging system design development envisions using off-site vendors for the design of the vertical casks and HAMs. Qualified vendors who express an interest in providing either cask or HAM designs, or both, will be asked to submit a response to a Request for Proposal (RFP) to provide design services for the Aging cask and on-site transportation equipment.

The development of specifications for the Aging cask and transporters envisions two major initial activities. The first step is develop a performance specification(s) that is specific to the YMP site. This is a current activity and is discussed further in Section 3.3. The second is to examine existing cask systems licensed per 10 CFR 72 and evaluate their suitability for meeting the performance specification(s) unique to YMP. This is also a current activity and is discussed further in Section 3.4.

A vendor familiar with CSNF dry storage facilities will produce a design specification for the aging cask and cask transporters. The specification will consider the CSNF types from around the nation that will be accommodated by the system. The specifications will be based on calculations and analyses that are conducted specifically for YMP. Calculations and analyses will include the following specific issues:

- Structural

- Thermal

- Seismic

- Radiological

- Environmental and Meteorological

\subsection{Licensing per 10 CFR 63}

The Aging system design will be submitted to the U.S. Nuclear Regulatory Commission (NRC) as part of the Yucca Mountain Repository License Application Safety Analysis Report (DOE 2005 [DIRS 170675]). The aging portion of the license application and the accompanying Safety Analysis Report (SAR) will be based on conceptual design drawings and calculations. The license application will be produced by DOE subcontractor personnel and will be based on the requirements in 10 CFR 63, Disposal of High-Level Radioactive Wastes in a Geologic Repository (10 CFR 63 [DIRS 156605]). The license application will be produced to satisfy the acceptance criteria in the Yucca Mountain Review Plan, Final Report (NRC 2003 [DIRS 163274]).

The Aging system strategy will be to submit a design that is similar to what would be submitted under 10 CFR 72. The Aging system at YMP will use as guidance the Standard Review Plan for Dry Cask Storage Systems (NRC 1997 [DIRS 101903]). However, there may be some differences between 10 CFR 63 and 10 CFR 72 that require design modifications to existing cask systems. The licensing strategy for the Aging system casks is to use 10 CFR 72 as reference only for design criteria, and adapt the 10 CFR 72 designs, as needed, to assure compliance with 10 CFR 63. The strategy includes requesting dry storage cask vendors to evaluate current 10 CFR 72 criteria and determine whether the 10 CFR 63 criteria are satisfied by current licensed 
designs. Differences between 10 CFR 63 and 10 CFR 72 will be noted and addressed as the evaluation of existing cask designs is moved forward.

\subsection{Final Design}

Final design of the Aging system components (aging casks, transfer equipment, foundations, alara concerns, etc.) is expected to commence during the licensing phase of YMP. After submittal of the SAR, the NRC is expected to take up to three years to review the documentation (see Section 8). The current YMP SAR information for the Aging system is based on a conceptual design. As the SAR is reviewed and preliminary design details are finalized, the final configuration of the Aging system can be further developed. The final design will incorporate changes that result from the NRC's review of the SAR.

\subsection{Fabrication and Implementation}

In the future, when licensing activities are completed, the Aging system components will be acquired. The vertical site-specific casks and HAMs, along with the transfer trailers and cask transporters, will be procured by DOE. The strategy will be to use, to the extent practicable, existing vendors and fabricators who are currently providing dry cask storage services to the nuclear power industry. Due to the variety of CSNF types that may be received at the repository, Aging system cask fabrication, delivery, and implementation will need to be coordinated with the waste stream being delivered to the repository. Matching the procurement of aging casks with the transportation schedule and delivery of CSNF from around the nation will require considerable lead time to assure that necessary Aging systems are available as needed. The strategy for implementation will require considerable flexibility for handling an incoming waste stream that contains a variety of materials with differing aging requirements.

\section{Summary of Completed Activities}

Design development of Aging structures, systems, and components (SSC)s is currently in the conceptual stage. Initial work to support the submittal of the SAR for geologic disposal of CSNF at YMP included compiling requirements and producing a conceptual design. The SNF Aging System Description Document (BSC 2004 [DIRS 171161]) contains the current set of design requirements and a conceptual design of the system. The conceptual design of the Aging system is nearing completion and will be followed by a preliminary design phase.

\subsection{Conceptual Design Development}

The project has completed a number of conceptual studies, calculations, and drawings that provide details of the Aging system that must be further developed. The current strategy for fiscal year 2005 is to advance the current conceptual design and further refine the Yucca Mountain Repository License Application Safety Analysis Report (DOE 2005 [DIRS 170765]). Table 3-1 summarizes the work accomplished by listing currently controlled Aging system calculations. The Aging strategy includes building upon and refining the work accomplished to

date. The summary of calculations does not include thermal management reports or transportation analyses since those issues are handled by other departments. However, the Aging system design does consider those issues and the present design is flexible. The aging 
conceptual design and strategy have been integrated with repository thermal management and transportation strategies to the extent practicable at this time.

Table 3-1 Summary of Controlled Aging System Calculations

\begin{tabular}{|l|l|l|}
\hline Document Title & Document Identifier & Effective Date \\
\hline Aging Facility Criticality Safety Calculations & $170-00 \mathrm{C}-$ HA00-00100-000-00B & September 10, 2004 \\
\hline $\begin{array}{l}\text { Design of a Concrete Slab for Storage of SNF } \\
\text { and HLW casks }\end{array}$ & $170-00 \mathrm{C}-$ HAP0-00100-000-00B & $\begin{array}{l}\text { Pending } \\
\text { (February 2005) }\end{array}$ \\
\hline $\begin{array}{l}\text { Shielding Evaluations for Spent Nuclear Fuel } \\
\text { Aging Areas }\end{array}$ & $170-00 \mathrm{C}-$ HAP0-00200-000-00A & May 10, 2004 \\
\hline $\begin{array}{l}\text { Dose Rate Evaluations for Spent Nuclear Fuel } \\
\text { Aging Areas }\end{array}$ & $170-00 \mathrm{C}-$ HAP0-00400-000-00A & December 16, 2004 \\
\hline $\begin{array}{l}\text { Midway Valley Aging Site Layout Drawing } \\
\text { Support Calculation }\end{array}$ & $170-$ COC-C000-00100-000-00A & March 26, 2004 \\
\hline
\end{tabular}

Project drawings of the Aging system have also been prepared to support the YMP SAR. Drawings include block flow diagrams, mechanical equipment envelopes, mechanical flow diagrams, site layout plans, and instrumentation diagrams that are available to support forward moving design development. These drawings are part of the conceptual design. Table 3-2 summarizes currently controlled Aging system drawings. These drawings represent the work completed through the first quarter of fiscal year 2005.

Table 3-2 Summary of Controlled Aging System Drawings

\begin{tabular}{|l|l|l|}
\hline Aging System Drawing Title & Document Identifier & Approval Date \\
\hline $\begin{array}{l}\text { Geologic Repository Operations Area Aging } \\
\text { Site Plan }\end{array}$ & $170-$ C00-MGR0-00101-000-00A & March 26, 2004 \\
\hline $\begin{array}{l}\text { Spent Nuclear Fuel Aging Area 1000 MTHM } \\
\text { Aging Module Concrete Plan and Sections }\end{array}$ & $170-$ DBO-HAP0-00101-000-00A & May 7, 2004 \\
\hline $\begin{array}{l}\text { SNF Aging System Instrument Systems } \\
\text { Functional Block Diagram }\end{array}$ & $170-$ J00-HA00-00101-000-00A & April 26, 2004 \\
\hline $\begin{array}{l}\text { SNF Aging System Block Flow Diagram } \\
\text { Level 2 }\end{array}$ & $170-M H 0-H A 00-00101-000-00 \mathrm{~A}$ & April 23, 2004 \\
\hline $\begin{array}{l}\text { SNF Aging System Block Flow Diagram } \\
\text { Level 3 (Sheet 1 of 2) }\end{array}$ & $170-M H 0-H A 00-00201-000-00 \mathrm{~A}$ & April 23, 2004 \\
\hline $\begin{array}{l}\text { SNF Aging System Block Flow Diagram } \\
\text { Level 3 (Sheet 2) }\end{array}$ & $170-M H 0-H A 00-00202-000-00 \mathrm{~A}$ & April 22, 2004 \\
\hline $\begin{array}{l}\text { SNF Aging System Mechanical Flow Diagram } \\
\text { (Sheet 1 of 3) }\end{array}$ & $170-M H 0-H A 00-00301-000-00 \mathrm{~A}$ & April 22, 2004 \\
\hline $\begin{array}{l}\text { SNF Aging System Mechanical Flow Diagram } \\
\text { (Sheet 2) }\end{array}$ & $170-M H 0-H A 00-00302-000-00 \mathrm{~A}$ & April 22, 2004 \\
\hline $\begin{array}{l}\text { SNF Aging System Mechanical Flow Diagram } \\
\text { (Sheet 3) }\end{array}$ & $170-M H 0-H A 00-00303-000-00 \mathrm{~A}$ & April 22, 2004 \\
\hline $\begin{array}{l}\text { SNF Aging System Mobile Crane Mechanical } \\
\text { Equipment Envelope }\end{array}$ & $170-M J 0-H A P 0-00101-000-00 \mathrm{~A}$ & April 22, 2004 \\
\hline
\end{tabular}




\begin{tabular}{|l|l|l|}
\hline Aging System Drawing Title & Document Identifier & Approval Date \\
\hline $\begin{array}{l}\text { SNF Aging System NUHOMS MP187 } \\
\text { Transport Cask Cart Mechanical Equipment } \\
\text { Envelope }\end{array}$ & 170-MQ0-HAT0-00101-000-00A & April 21, 2004 \\
\hline $\begin{array}{l}\text { SNF Aging System NUHOMS MP197 } \\
\text { Transport Cask Cart Mechanical Equipment } \\
\text { Envelope }\end{array}$ & $170-$ MQ0-HAT0-00201-000-00A & April 21, 2004 \\
\hline $\begin{array}{l}\text { SNF Aging System Cask Tractor Mechanical } \\
\text { Equipment Envelope }\end{array}$ & $170-$ MQ0-HAT0-00301-000-00A & April 22, 2004 \\
\hline $\begin{array}{l}\text { SNF Aging System MSC Transporter } \\
\text { Mechanical Equipment Envelope }\end{array}$ & $170-$ MQ0-HAT0-00401-000-00A & April 21, 2004 \\
\hline $\begin{array}{l}\text { SNF Aging System HMSC Cart Mechanical } \\
\text { Equipment Envelope }\end{array}$ & $170-$ MQ0-HAT0-00501-000-00A & April 21, 2004 \\
\hline $\begin{array}{l}\text { SNF Aging System Mobile Platform } \\
\text { Mechanical Equipment Envelope }\end{array}$ & $170-M X 0-H A P 0-00101-000-00 \mathrm{~A}$ & April 21, 2004 \\
\hline
\end{tabular}

\subsection{Nuclear Safety Design Bases}

The YMP has established a set of requirements to assure preclosure nuclear safety of the Aging system. As the Aging system design moves forward, satisfaction of the nuclear safety design bases will provide reasonable assurance that the performance objective of 10 CFR 63 (10 CFR 63 [DIRS 156605]) will be met. The design development strategy will progress with the specific intention to assure that the design bases from Nuclear Safety Design Bases for License Application (BSC 2005 [DIRS 171512], Table A-II) are satisfied. The proposed design bases for Aging system SSCs are summarized in Tables 3-3 through 3-9.

Table 3-3 Cask Tractor, HAM System - Nuclear Safety Design Bases

\begin{tabular}{|c|c|}
\hline Aging Subsystem & Nuclear Safety Design Basis \\
\hline \multirow[t]{8}{*}{$\begin{array}{l}\text { Cask Tractor - HAM } \\
\text { Subsystem }\end{array}$} & $\begin{array}{l}\text { The cask tractor shall be designed to limit collision impact loads to values that assure waste } \\
\text { container integrity. }\end{array}$ \\
\hline & The cask tractor brake system shall be designed to prevent a cask tractor runaway event. \\
\hline & $\begin{array}{l}\text { The design of the horizontal cask transfer trailer/tractor shall limit the size, mass, maximum } \\
\text { speed, and motive force to limit potential damage caused by collisions. }\end{array}$ \\
\hline & Fires and explosions shall be precluded from initiating a cask tractor event sequence. \\
\hline & Loss of power events shall be precluded from initiating a cask tractor event sequence. \\
\hline & $\begin{array}{l}\text { Tip-over during transfer shall be precluded by ensuring that minimum tip-over } \\
\text { resistance/standards are maintained consistent with roadway design. }\end{array}$ \\
\hline & $\begin{array}{l}\text { The design of the horizontal cask transfer trailer tractor shall provide reliable means to stop } \\
\text { and maintain stability. }\end{array}$ \\
\hline & $\begin{array}{l}\text { The cask tractor shall be designed for loading conditions associated with a Design Basis } \\
\text { Ground Motion-2 level seismic event and demonstrate sufficient margin to a "no runaway" } \\
\text { safety function for loading conditions associated with a Beyond Design Basis Ground Motion- } \\
\text { level seismic event. }\end{array}$ \\
\hline
\end{tabular}


Table 3-4 Transfer Trailer, HAM System - Nuclear Safety Design Bases

\begin{tabular}{|l|l|}
\hline Aging Subsystem & Nuclear Safety Design Basis \\
\hline Transfer Trailer - & $\begin{array}{l}\text { The design of the hydraulic ram shall ensure that it cannot fail or be operated in a manner } \\
\text { that can cause DPC loss of function through excess force or ram over-travel. }\end{array}$ \\
\cline { 2 - 3 } & $\begin{array}{l}\text { The horizontal cask transfer trailer shall be designed for loading conditions associated with a } \\
\text { Design Basis Ground Motion-2 level seismic event and demonstrate sufficient margin to "no } \\
\text { slapdown" and "no runaway" safety functions for loading conditions associated with a Beyond } \\
\text { Design Basis Ground Motion-level seismic event. }\end{array}$ \\
\cline { 2 - 3 } & $\begin{array}{l}\text { The design of the horizontal cask transfer trailer shall limit the maximum potential drop } \\
\text { height. }\end{array}$ \\
\cline { 2 - 3 } & $\begin{array}{l}\text { The design of the horizontal cask transfer trailer/tractor shall limit the size, mass, maximum } \\
\text { speed, and motive force to limit potential damage caused by collisions. }\end{array}$ \\
\hline & $\begin{array}{l}\text { The design of the horizontal cask transfer trailer shall preclude tip-over during transfer by } \\
\text { ensuring that the transfer equipment design precludes failure modes that could result in tip- } \\
\text { over under design basis load handling conditions. }\end{array}$ \\
\hline & $\begin{array}{l}\text { The design of the horizontal cask transfer trailer shall preclude tip-over during transfer by } \\
\text { ensuring minimum tip-over resistance/stability standards are maintained consistent with } \\
\text { roadway design. }\end{array}$ \\
\hline & \begin{tabular}{l} 
Fires and explosions shall be precluded from initiating a HAM transfer trailer event sequence. \\
\hline
\end{tabular}
\end{tabular}

Table 3-5 Site-Specific Cask Transporter - Nuclear Safety Design Bases

\begin{tabular}{|c|c|}
\hline Aging Subsystem & Nuclear Safety Design Basis \\
\hline \multirow[t]{11}{*}{$\begin{array}{l}\text { Site-Specific Cask } \\
\text { Transporter }\end{array}$} & $\begin{array}{l}\text { The site-specific cask transporter shall be designed for loading conditions associated with a } \\
\text { Design Basis Ground Motion-2 level seismic event and demonstrate sufficient margin to "no } \\
\text { slapdown" and "no runaway" safety functions for loading conditions associated with a Beyond } \\
\text { Design Basis Ground Motion-level seismic event. }\end{array}$ \\
\hline & $\begin{array}{l}\text { A speed limit for the site-specific cask transporter shall be established such that a collision } \\
\text { with shield or airlock doors or other heavy objects does not overturn the site-specific cask } \\
\text { transporter or cause it to drop its load. }\end{array}$ \\
\hline & $\begin{array}{l}\text { The cask transporter shall prevent lifting the aging and transfer casks above their maximum } \\
\text { handling height. }\end{array}$ \\
\hline & The design of the site-specific cask transporter shall limit the maximum potential drop height. \\
\hline & $\begin{array}{l}\text { The design of the site-specific cask transporter shall limit the size, mass, maximum speed, } \\
\text { and motive force to limit potential damage caused by collisions. }\end{array}$ \\
\hline & $\begin{array}{l}\text { The design of the site-specific cask transporter shall preclude tip-over during transfer by } \\
\text { ensuring that the transfer equipment design precludes failure modes that could result in tip- } \\
\text { over under design basis load handling conditions. }\end{array}$ \\
\hline & $\begin{array}{l}\text { The design of the site-specific cask transporter shall preclude tip-over during transfer by } \\
\text { ensuring minimum tip-over resistance/stability standards are maintained consistent with } \\
\text { roadway design. }\end{array}$ \\
\hline & $\begin{array}{l}\text { The design of the site-specific cask transporter shall provide reliable means to stop and } \\
\text { maintain stability. }\end{array}$ \\
\hline & $\begin{array}{l}\text { Fires and explosions shall be precluded from initiating a site-specific cask transporter event } \\
\text { sequence. }\end{array}$ \\
\hline & Loss of power events shall be precluded from initiating a site-specific cask event sequence. \\
\hline & $\begin{array}{l}\text { Upon a loss of power, the transporter shall be designed to stop, retain the load, and enter a } \\
\text { locked mode; upon a restoration of power, the transporter shall stay in the locked mode until } \\
\text { operator action is taken. }\end{array}$ \\
\hline
\end{tabular}


Table 3-6 Site-Specific Transfer Cask - Nuclear Safety Design Bases

\begin{tabular}{|l|l|}
\hline Aging Subsystem & Nuclear Safety Design Basis \\
\hline $\begin{array}{l}\text { Site-Specific } \\
\text { Transfer Cask }\end{array}$ & $\begin{array}{l}\text { The design of aging and transfer casks shall ensure that they can withstand a drop from the } \\
\text { maximum handling height of a horizontal cask transfer trailer without loss of function. }\end{array}$ \\
\cline { 2 - 3 } & $\begin{array}{l}\text { The design of the horizontal transportation and transfer casks shall ensure that they can } \\
\text { withstand a drop of heavy objects handled during transfer operations; e.g., access cover } \\
\text { plate, from the maximum handling height without adverse effects. }\end{array}$ \\
\cline { 2 - 2 } & $\begin{array}{l}\text { Lightning strikes shall be precluded from initiating a site-specific transfer cask event } \\
\text { sequence. }\end{array}$ \\
\hline
\end{tabular}

Table 3-7 Aging Pad - Nuclear Safety Design Bases

\begin{tabular}{|c|c|}
\hline Aging Subsystem & Nuclear Safety Design Basis \\
\hline \multirow[t]{8}{*}{ Aging Pad } & $\begin{array}{l}\text { The design of the aging pad shall ensure that it is capable of performing functions that are } \\
\text { important to safety during a maximum probable flood. }\end{array}$ \\
\hline & $\begin{array}{l}\text { The aging pad shall be located to avoid placement directly over surface or near-surface } \\
\text { faults. }\end{array}$ \\
\hline & $\begin{array}{l}\text { The surface aging pad shall be designed for loading conditions associated with a Design } \\
\text { Basis Ground Motion-2 level seismic event and demonstrate sufficient margin to a "no } \\
\text { significant cracking/displacement" safety function for loading conditions associated with a } \\
\text { Beyond Design Basis Ground Motion-level seismic event. }\end{array}$ \\
\hline & $\begin{array}{l}\text { To reduce the likelihood of a meteorite strike that could breach a cask, the exposed area on } \\
\text { the aging pads shall not exceed } 15 \text { percent density of the pad area, with an associated } \\
\text { aggregate exposed cross-sectional area less than } 360,000 \text { square feet, for the case involving } \\
20,000 \text { metric tons of heavy metal. }\end{array}$ \\
\hline & $\begin{array}{l}\text { The structure shall be designed for the loads associated with a precipitation intensity of } \\
2.15 \mathrm{in} . / \mathrm{hr} \text {. }\end{array}$ \\
\hline & Lightning strikes shall be precluded from initiating an aging pad event sequence. \\
\hline & $\begin{array}{l}\text { Surface facilities associated with the Aging system, where CSNF is handled or stored shall } \\
\text { be designed to withstand the effects of a regional volcanic eruption without loss of capacity to } \\
\text { perform their safety function. }\end{array}$ \\
\hline & $\begin{array}{l}\text { A barrier surrounding the aging pads shall ensure that the conditional probability of a skid-in } \\
\text { impact and entry by aircraft from the side of the aging pad that would result in radiological } \\
\text { consequences is } 0.01 \text { or less. }\end{array}$ \\
\hline
\end{tabular}


Table 3-8 Site-Specific Cask - Nuclear Safety Design Bases

\begin{tabular}{|c|c|}
\hline Aging Subsystem & Nuclear Safety Design Basis \\
\hline \multirow[t]{17}{*}{ Site-Specific Cask } & $\begin{array}{l}\text { The site-specific casks and other vertical aging systems shall be designed for loading } \\
\text { conditions associated with a Design Basis Ground Motion-2 level seismic event and } \\
\text { demonstrate sufficient margin to "no tip-over" and "no breach" safety functions for loading } \\
\text { conditions associated with a Beyond Design Basis Ground Motion-level seismic event. }\end{array}$ \\
\hline & $\begin{array}{l}\text { Tip-over or displacement of aging casks as a result of extreme wind or tornado events shall } \\
\text { be precluded. }\end{array}$ \\
\hline & $\begin{array}{l}\text { Tip-over or displacement of aging casks as a result of differential pressure associated with a } \\
\text { passing tornado shall be precluded. }\end{array}$ \\
\hline & $\begin{array}{l}\text { The design of aging casks shall ensure that they can withstand the differential pressure } \\
\text { associated with a passing tornado without loss of function. }\end{array}$ \\
\hline & $\begin{array}{l}\text { Tip-over or displacement of aging casks as a result of being struck by a design basis tornado } \\
\text { missile shall be precluded. }\end{array}$ \\
\hline & $\begin{array}{l}\text { The design of aging casks shall ensure that they can withstand being struck by a design } \\
\text { basis tornado missile without loss of function. }\end{array}$ \\
\hline & $\begin{array}{l}\text { The design of aging casks shall ensure that they can withstand a drop from the maximum } \\
\text { handling height of a site-specific transporter without loss of function. }\end{array}$ \\
\hline & $\begin{array}{l}\text { The design of aging casks shall ensure that they can withstand limited hydrogen explosions } \\
\text { or fires involving batteries or limited quantities of fuel without loss of function. }\end{array}$ \\
\hline & $\begin{array}{l}\text { The design of the casks shall ensure acceptable thermal design performance during extreme } \\
\text { temperature events based on YMP historical climate data. }\end{array}$ \\
\hline & $\begin{array}{l}\text { Short-duration vent blockage events involving site-specific casks shall be precluded from } \\
\text { initiating an event sequence. }\end{array}$ \\
\hline & $\begin{array}{l}\text { Maximum snow, sand, or ash loads shall be precluded from initiating an event sequence } \\
\text { involving site-specific casks. }\end{array}$ \\
\hline & $\begin{array}{l}\text { The design of the casks shall ensure that welded closure casks/canister confinement system } \\
\text { designs preclude loss of confinement during life cycle operations and events following } \\
\text { closure. }\end{array}$ \\
\hline & $\begin{array}{l}\text { The design of the site-specific cask shall ensure that bolted closure cask design protects } \\
\text { seals from damage during life cycle operations and events following closure to maintain its } \\
\text { primary confinement boundary function. }\end{array}$ \\
\hline & $\begin{array}{l}\text { Site-specific casks shall be designed to ensure nuclear criticality safety with optimum } \\
\text { moderation and the most reactive waste forms despite any geometric rearrangements due to } \\
\text { a drop or other handling incident. }\end{array}$ \\
\hline & $\begin{array}{l}\text { In case of a fire, the wall temperature of a loaded site-specific cask, being handled or at rest, } \\
\text { shall not exceed its allowable operating range. }\end{array}$ \\
\hline & $\begin{array}{l}\text { In case of a fire, the wall temperature of a loaded site-specific cask with docking ring installed } \\
\text { shall not exceed its allowable operating range. }\end{array}$ \\
\hline & Lightning strikes shall be precluded from initiating a site-specific cask event sequence. \\
\hline
\end{tabular}


Table 3-9 Horizontal Aging Module - Nuclear Safety Design Bases

\begin{tabular}{|c|c|}
\hline Aging Subsystem & Nuclear Safety Design Basis \\
\hline \multirow[t]{15}{*}{$\begin{array}{l}\text { Horizontal Aging } \\
\text { Module }\end{array}$} & $\begin{array}{l}\text { The HAM systems shall be designed for loading conditions associated with a Design Basis } \\
\text { Ground Motion-2 level seismic event and demonstrate sufficient margin to a "no collapse" } \\
\text { safety function for loading conditions associated with a Beyond Design Basis Ground Motion- } \\
\text { level seismic event. }\end{array}$ \\
\hline & Lightning strikes shall be precluded from initiating a HAM event sequence. \\
\hline & $\begin{array}{l}\text { Tip-over or displacement of HAMs as a result of extreme wind or tornado events shall be } \\
\text { precluded. }\end{array}$ \\
\hline & $\begin{array}{l}\text { Tip-over or displacement of HAMs as a result of differential pressure associated with a } \\
\text { passing tornado shall be precluded. }\end{array}$ \\
\hline & $\begin{array}{l}\text { The design of HAMs shall ensure that they can withstand the differential pressure associated } \\
\text { with a passing tomado without loss of function. }\end{array}$ \\
\hline & $\begin{array}{l}\text { Tip-over or displacement of HAMs as a result of being struck by a design basis tornado } \\
\text { missile shall be precluded. }\end{array}$ \\
\hline & $\begin{array}{l}\text { The design of HAMs shall ensure that they can withstand being struck by a design basis } \\
\text { tornado missile without loss of function. }\end{array}$ \\
\hline & $\begin{array}{l}\text { The design of HAMs shall ensure that they can withstand limited hydrogen explosions or fires } \\
\text { involving batteries or limited quantities of fuel without loss of function. }\end{array}$ \\
\hline & $\begin{array}{l}\text { The design of the HAMs shall ensure acceptable thermal design performance during extreme } \\
\text { temperature events based on YMP historical climate data. }\end{array}$ \\
\hline & $\begin{array}{l}\text { Short-duration vent blockage events involving HAMs shall be precluded from initiating an } \\
\text { event sequence. }\end{array}$ \\
\hline & $\begin{array}{l}\text { Maximum snow, sand, or ash loads shall be precluded from initiating an event sequence } \\
\text { involving HAMs. }\end{array}$ \\
\hline & $\begin{array}{l}\text { The design of the HAMs shall ensure that welded closure casks/canister confinement system } \\
\text { designs preclude loss of confinement during life cycle operations and events following } \\
\text { closure. }\end{array}$ \\
\hline & Fires and explosions shall be precluded from initiating a HAM event sequence. \\
\hline & $\begin{array}{l}\text { The HAMs shall be designed to withstand the effects of a regional volcanic eruption without } \\
\text { loss of capacity to perform their safety function. }\end{array}$ \\
\hline & $\begin{array}{l}\text { The design of the horizontal DPC shall ensure that it has sufficient structural design margin } \\
\text { to withstand maximum ram force events. }\end{array}$ \\
\hline
\end{tabular}

\subsection{Recent Aging Strategy, Performance Specification}

With the completion of the conceptual design for the YMP SAR (DOE 2005 [DIRS 170675], Section 1.2.7), the Aging design team has advanced the aging program by issuing a subcontract for the development of a technical performance specification for vertical site-specific casks, HAMs, and supporting site transport equipment. A subcontractor has been requested to prepare a technical performance specification for the design and fabrication of site-specific casks with matching cask transfer equipment (BSC 2004 [DIRS 172746]). The technical performance specification must be developed to meet the proposed nuclear safety design bases in Tables 3-3 through 3-9. 


\subsection{Recent Aging Strategy, Comparative Report}

The current strategy for the aging cask design is to use currently developed CSNF dry storage systems modified, as required, to meet 10 CFR 63 . The aging design team is currently in the process of requesting information from cask vendors to compare currently licensed designs and their performance criteria with the performance objectives for YMP. Performance objectives for YMP have been established in a scope of work document (BSC 2005 [DIRS 172747]), and the strategy entails evaluating current cask designs for compliance with YMP performance objectives and YMP site-specific hazards. This requires comparisons of current storage system designs to YMP site-specific requirements and analysis of the existing designs for compatibility with YMP criteria. Establishing the required design changes to currently licensed 10 CFR 72 systems for implementation at YMP is follow-on work.

\section{Remaining Activities Leading to Implementation}

Design development of the YMP site-specific Aging system activities have been grouped into seven principle areas or phases. The areas are listed below. The timeframe for these activities overlap. Licensing and regulatory support and interaction functions span nearly all phases. Design development of the Aging system is dependent on regulatory approval at various stages, though licensing is not directly considered a design function.

- Requirements and Specification Development (currently in-process)

- Conceptual Design, License Application, and Safety Analysis Report (currently in-process)

- Preliminary Design (Table 4-1)

- Final Design (Table 4-2)

- Licensing (Table 4-3) (currently in-process)

- Fabrication (Table 4-4)

- Implementation (Table 4-5)

The design development strategy for the remaining activities is dependent on schedule and scope advancement. The initial scope of Aging system design development and a preliminary schedule is outlined in the following sections. The activities and schedule will be more fully developed as the design advances and as project issues are resolved.

\subsection{Preliminary Design}

The preliminary design activities are summarized in the following tables and provide an outline of the path forward. The activities discussed previously in Section 3 and the documents listed in Tables 3-1 and 3-2 reflect the current conceptual design. The preliminary design will advance the conceptual design. The conceptual design is flexible, though the expectation is that the preliminary design will not differ significantly from the SAR conceptual design. 
Table 4-1 Preliminary Design Activities

\begin{tabular}{|c|c|c|c|}
\hline $\begin{array}{l}\text { Preliminary } \\
\text { Design } \\
\text { (30 percent) }\end{array}$ & Activity & Activity Description & Time Frame \\
\hline \multirow[t]{11}{*}{$\begin{array}{l}\text { Preliminary } \\
\text { Design }\end{array}$} & Package Contents & $\begin{array}{l}\text { Establish preliminary calculations, drawings, } \\
\text { reports, and specifications that comprise the YMP } \\
\text { Aging system SSCs }\end{array}$ & FY 2006 \\
\hline & $\begin{array}{l}\text { Establish } \\
\text { Requirements }\end{array}$ & $\begin{array}{l}\text { Finalize the requirements for the storage casks and } \\
\text { other Aging SSCs. Identify appropriate codes and } \\
\text { standards. }\end{array}$ & FY 2005 \\
\hline & Establish Interfaces & $\begin{array}{l}\text { Specify interfaces between cask and surface } \\
\text { repository facility systems. }\end{array}$ & FY 2006 \\
\hline & $\begin{array}{l}\text { Evaluate Existing } \\
\text { Storage Cask } \\
\text { Systems }\end{array}$ & $\begin{array}{l}\text { Summarize the existing horizontal and vertical } \\
\text { storage systems that may be used at Yucca } \\
\text { Mountain and establish which features will need } \\
\text { evaluation to adapt the existing design to Yucca } \\
\text { Mountain. }\end{array}$ & FY 2005 \\
\hline & $\begin{array}{l}\text { Develop Design } \\
\text { Inputs }\end{array}$ & $\begin{array}{l}\text { Specify the inputs for the site-specific cask systems } \\
\text { derived from the repository design, spent fuel } \\
\text { configurations, and other considerations. }\end{array}$ & FY 2005 \\
\hline & $\begin{array}{l}\text { Bounding } \\
\text { Conditions }\end{array}$ & Establish bounding conditions for cask designs. & FY 2006 \\
\hline & $\begin{array}{l}\text { Develop Storage } \\
\text { Cask Designs }\end{array}$ & $\begin{array}{l}\text { Complete design of horizontal and vertical systems } \\
\text { to approximately } 30 \text { percent complete. Complete } \\
\text { required structural, seismic, thermal, and } \\
\text { radiological analyses. }\end{array}$ & FY 2006 \\
\hline & $\begin{array}{l}\text { Develop Transfer } \\
\text { System Designs }\end{array}$ & $\begin{array}{l}\text { Complete design of horizontal and vertical transfer } \\
\text { systems to approximately } 30 \text { percent complete. } \\
\text { Complete required analyses. }\end{array}$ & FY 2006 \\
\hline & $\begin{array}{l}\text { Reliability and } \\
\text { Risks }\end{array}$ & $\begin{array}{l}\text { Identify the risks associated with the preliminary } \\
\text { design and any reliability issues. }\end{array}$ & FY 2006 \\
\hline & Perform Reviews & Conduct preliminary design reviews & FY 2006 \\
\hline & $\begin{array}{l}\text { Identify any Needed } \\
\text { Testing }\end{array}$ & $\begin{array}{l}\text { Identify any unresolved issues that may need } \\
\text { further testing or evaluation. }\end{array}$ & FY 2006 \\
\hline
\end{tabular}

\subsection{Final Design}

Final design of the Aging system components will be based on the preliminary design that was submitted to the NRC as part of the YMP SAR. Final design will produce a suite of detailed drawings and specifications that will be used to procure the Aging system vertical casks, HAMs, and transfer equipment. 
Table 4-2 Final Design Activities

\begin{tabular}{|l|l|l|l|}
\hline $\begin{array}{l}\text { Final Design } \\
\text { (100 percent } \\
\text { complete) }\end{array}$ & Activity & Activity Description & Time Frame \\
\hline Final Design & $\begin{array}{l}\text { Final Design } \\
\text { Drawings }\end{array}$ & $\begin{array}{l}\text { Complete set of drawings for vertical and horizontal } \\
\text { cask system. }\end{array}$ & $\begin{array}{l}\text { FY } 2007 \text { and } \\
\text { FY } 2008\end{array}$ \\
\cline { 2 - 4 } & $\begin{array}{l}\text { Establish Baseline } \\
\text { and Implement } \\
\text { Formal Change } \\
\text { Control }\end{array}$ & $\begin{array}{l}\text { Formally control the final design and ensure that } \\
\text { changes are appropriately controlled, documented, } \\
\text { and communicated. }\end{array}$ & FY 2008 \\
\cline { 2 - 4 } & $\begin{array}{l}\text { Verification of } \\
\text { Design }\end{array}$ & $\begin{array}{l}\text { Conduct formal verification of the horizontal and } \\
\text { vertical designs. Verify implementation of the } \\
\text { design inputs, requirements, and satisfaction of } \\
\text { acceptance criteria. }\end{array}$ & FY 2008 \\
\cline { 2 - 4 } & $\begin{array}{l}\text { Approval of } \\
\text { Package for } \\
\text { Fabrication }\end{array}$ & $\begin{array}{l}\text { Issue approval package for the storage and } \\
\text { transfer systems. }\end{array}$ & FY 2008 \\
\hline
\end{tabular}

\subsection{Licensing}

Licensing activities span all phases of the Aging system program. The SAR will be based on conceptual and preliminary design details. Submittal of the SAR to the NRC will be at the discretion of DOE. The state of the design at the time of the SAR submittal will be reflected in the SAR. As the design progresses, additional details will be provided to the NRC through amendments to the SAR. As the NRC reviews the SAR, the design development strategy recognizes that there will be requests for additional information. Those requests will be addressed during the final design phase of the Aging system.

Table 4-3 Licensing Activities

\begin{tabular}{|l|l|l|l|}
\hline Licensing & Activity & Activity Description & Time Frame \\
\hline Licensing & $\begin{array}{l}\text { Prepare Preliminary } \\
\text { Safety Analysis } \\
\text { Report }\end{array}$ & $\begin{array}{l}\text { Prepare, review, and finalize the aging section of } \\
\text { the Yucca Mountain Repository License Application } \\
\text { Safety Analysis Report (DOE 2005, [DIRS 170675]) }\end{array}$ & FY 2005 \\
\cline { 2 - 4 } & $\begin{array}{l}\text { Submit Final Safety } \\
\text { Analysis Report }\end{array}$ & $\begin{array}{l}\text { Finalize SAR input for aging and submit to NRC via } \\
\text { amendments to the SAR. }\end{array}$ & FY 2008 \\
\cline { 2 - 5 } & $\begin{array}{l}\text { Respond to } \\
\text { Requests for } \\
\text { Additional } \\
\text { Information }\end{array}$ & $\begin{array}{l}\text { Respond to NRC requests for additional } \\
\text { information. }\end{array}$ & $\begin{array}{l}\text { FY } 2006 \\
\text { through FY } \\
2008\end{array}$ \\
\cline { 2 - 4 } & $\begin{array}{l}\text { Receive License for } \\
\text { Storage Cask } \\
\text { Systems }\end{array}$ & $\begin{array}{l}\text { Receive license for aging components needed to } \\
\text { store CSNF in dry storage casks at YMP. }\end{array}$ & FY 2008 \\
\hline
\end{tabular}




\subsection{Fabrication and Implementation}

Fabrication of the Aging SSCs and implementation at YMP is included in this design development strategy plan for completeness only. Fabrication and implementation are the culmination of the design development program.

Table 4-4 Fabrication Activities

(To be developed and expanded at a future time.)

\begin{tabular}{|l|l|l|l|}
\hline Fabrication & Activity & Activity Description & Time Frame \\
\hline Fabrication & & Award Fabrication Contracts & FY 2008 \\
\cline { 2 - 4 } & & Fabricate Vertical Casks and HAMs & FY 2009 \\
\cline { 2 - 4 } & & Conduct Acceptance Testing & FY 2009 \\
\cline { 2 - 4 } & & Certify Storage Systems for Use & FY 2009 \\
\cline { 2 - 4 } & & Ship to Yucca Mountain & FY 2009 \\
\cline { 2 - 4 } & & Accept at Yucca Mountain & FY 2009 \\
\hline
\end{tabular}

Table 4-5 Implementation Activities

(To be developed and expanded at a future Time.)

\begin{tabular}{|l|l|l|l|}
\hline Implementation & Activity & Activity Description & Time Frame \\
\hline Implementation & & Load Casks and HAMs & FY 2010 \\
\cline { 2 - 4 } & & Transfer Casks and HAMs & FY 2010 \\
\cline { 2 - 4 } & & Monitor Casks and HAMs & FY 2010 \\
\cline { 2 - 4 } & & Return Aged CSNF to Handling Facility & Future \\
\cline { 2 - 4 } & & Transfer Aged CSNF to Waste Package & Future \\
\hline
\end{tabular}

\section{Conclusions}

An Aging system at YMP is necessary to accomplish project goals for thermal management as discussed in Thermal Management Study (BSC 2005 [DIRS 172739], Section 7.3). The design development strategy of the Aging system envisions the utilization and implementation of SSCs that are very similar to currently licensed systems. A performance specification for the aging casks and a comparative report to evaluate existing casks against YMP specific criteria will be completed in the near-term. Existing designs that are currently in service at nuclear power plants will be analyze for suitability for use at YMP.

\section{Acronyms}

CFR Code of Federal Regulations

CSNF commercial spent nuclear fuel

DOE U.S. Department of Energy

DPC dual-purpose canister 
FY fiscal year

$\begin{array}{ll}\text { HAM } & \begin{array}{l}\text { horizontal aging module } \\ \text { HLWh-level radioactive waste }\end{array} \\ \text { MCO } & \text { multi-canister overpack } \\ \text { NRC } & \text { U.S. Nuclear Regulatory Commission } \\ \text { RFP } & \text { request for proposal } \\ \text { SAR } & \begin{array}{l}\text { Safety Analysis Report } \\ \text { spent nuclear fuel }\end{array} \\ \text { SNF } & \text { structure, system, and component } \\ \text { SSC } & \text { Yucca Mountain Project }\end{array}$

\section{References}

101903 NRC (U.S. Nuclear Regulatory Commission) 1997. Standard Review Plan for Dry Cask Storage Systems. NUREG-1536. Washington, D.C.: U.S. Nuclear Regulatory Commission. ACC: MOL.20010724.0307.

12726710 CFR 72. Energy: Licensing Requirements for the Independent Storage of Spent Nuclear Fuel, High-Level Radioactive Waste, and Reactor-Related Greater than Class C Waste. Readily available.

15660510 CFR 63. Energy: Disposal of High-Level Radioactive Wastes in a Geologic Repository at Yucca Mountain, Nevada. Readily available.

163274 NRC (U.S. Nuclear Regulatory Commission) 2003. Yucca Mountain Review Plan, Final Report. NUREG-1804, Rev. 2. Washington, D.C.: U.S. Nuclear Regulatory Commission, Office of Nuclear Material Safety and Safeguards. TIC: 254568.

171161 BSC (Bechtel SAIC Company) 2004. SNF Aging System Description Document. 170-3YD-HA00-00100-000-003. Las Vegas, Nevada: Bechtel SAIC Company. ACC: ENG.20040916.0001.

171512 BSC (Bechtel SAIC Company) 2004. Nuclear Safety Design Bases for License Application. 000-30R-MGR0-00400-000-001. Las Vegas, Nevada: Bechtel SAIC Company. 
170675 DOE (U.S. Department of Energy) 2005. Yucca Mountain Repository License Application Safety Analysis Report. DOE/RW-0573, Rev 0. Washington, D.C.: U.S. Department of Energy, Office of Civilian Radioactive Waste Management.

172739 BSC (Bechtel SAIC Company) 2005. Thermal Management Study. 000-30RMGR0-00600-000-000. Las Vegas, Nevada: Bechtel SAIC Company. ACC: ENG.20050202.0053.

172746 BSC (Bechtel SAIC Company) 2004. Scope of Work, SNF Aging Casks/SiteSpecific Casks. 170-3SW-WA42-00100-000-001. Las Vegas, Nevada: Bechtel SAIC Company. ACC: ENG.20040915.0005.

172747 BSC (Bechtel SAIC Company) 2005. Scope of Work, Confirmation Report Yucca Mountain CSNF Aging Casks. 170-3SW-WA42-00200-000-000. Las Vegas, Nevada: Bechtel SAIC Company. ACC: ENG.20050203.0024. 
Aging System Design Development Strategy

INTENTIONALLY LEFT BLANK 


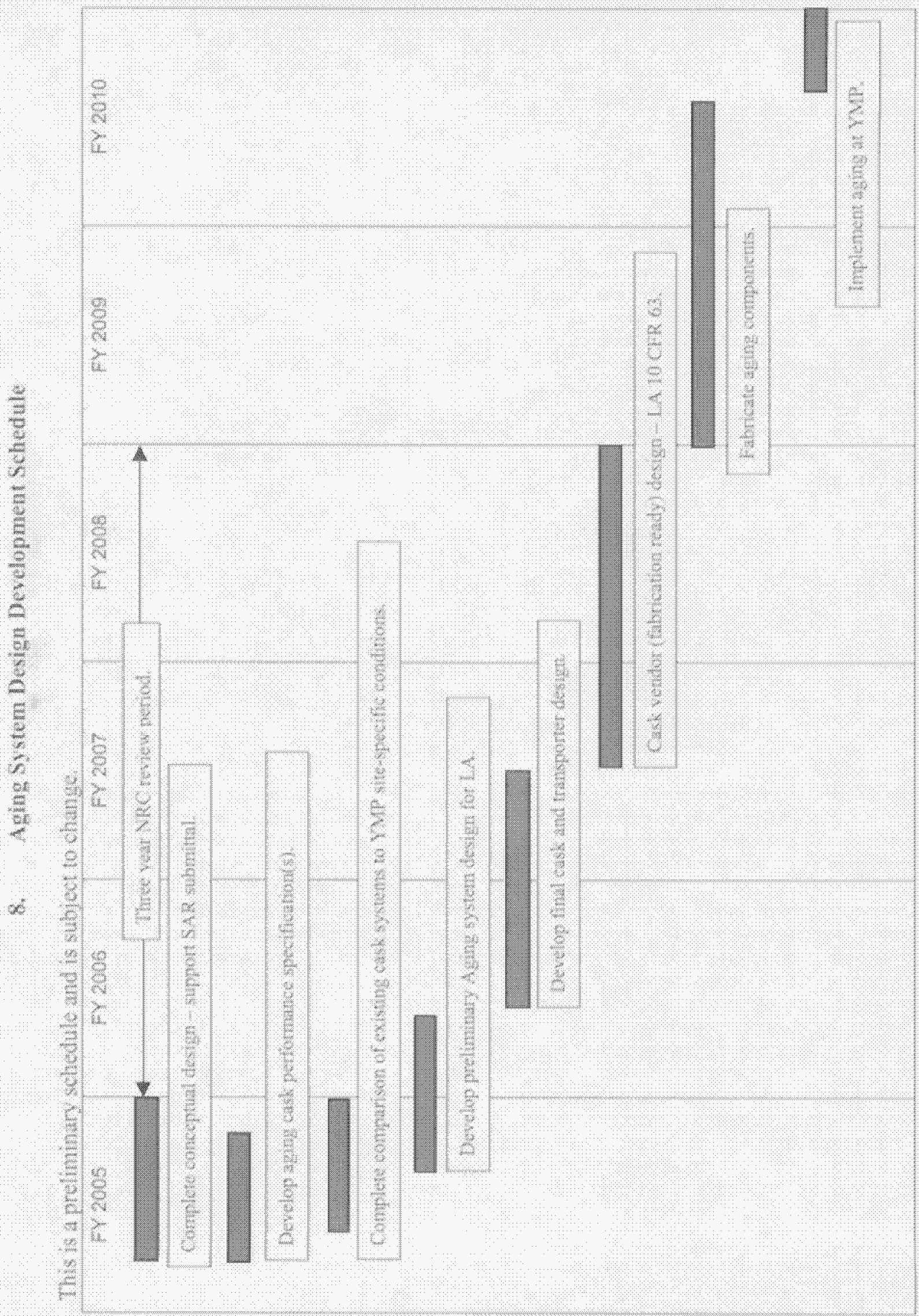


Aging System Design Development Strategy

INTENTIONALLY LEFT BLANK 